\title{
Integrated clinical treatment of external cervical resorption: Case report
}

\author{
Tratamento clínico integrado de reabsorção cervical: Relato de caso \\ Tratamiento clínico integrado de la reabsorción cervical: Reporte de caso
}

Received: 04/22/2021 | Reviewed: 04/30/2021 |Accept: 05/03/2021 | Published: 05/16/2021

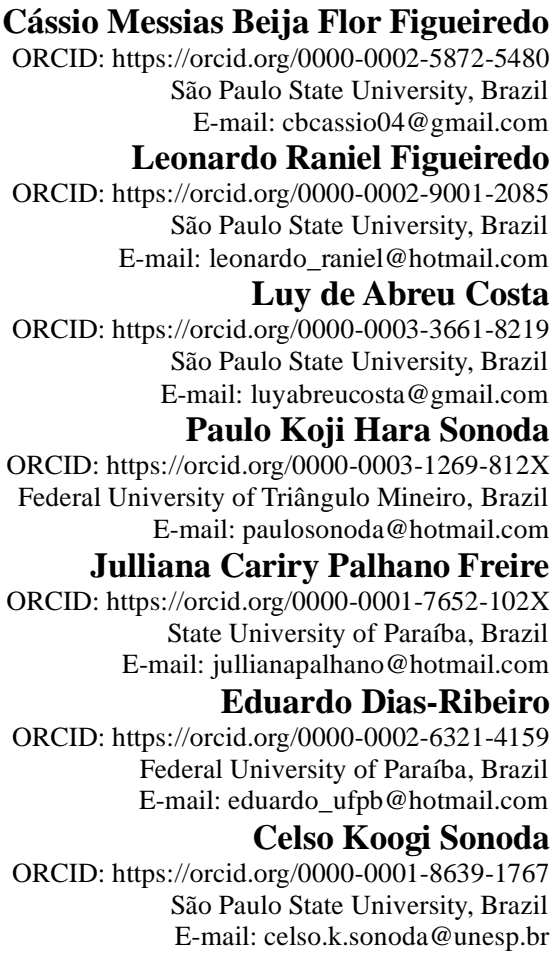

\begin{abstract}
External cervical resorption (ECR) has an inflammatory nature and the proximity to the gingival sulcus favors contamination and progression of the lesion. Change in crown color, inflammation of the marginal gingiva or even the presence of secretion in the gingival sulcus are the main clinical signs. Being an asymptomatic lesion, it can be neglected and its progression can jeopardize the tooth involved. This report describes the treatment of a patient who presented two teeth with ECR. On clinical examination, the crown of tooth 17 showed a pinkish translucency on the occlusal surface. On tooth 12, this spot was dark and located in the cervical third of the labial surface of the crown. Both the teeth were asymptomatic, and the radiographic examination showed an image comparable with root resorption in the cervical third of the crown. On tooth 17 , the middle and cervical third of the crown was compromised and the pulp vitality test was negative. The treatment for the case was extraction. A tomographic examination of tooth 12 demonstrated pulpal involvement and biologic width violation. The vitality test was positive. After endodontic treatment, the tooth was extruded by $4 \mathrm{~mm}$, the resorbed area was exposed and restored with composite resin. A 39-month clinical and radiographic control showed integrity of the root surface and the periodontium. It was found that early diagnosis influences the prognosis of treatment considering the speed of progression of resorption. It emphasizes the importance of clinical and radiographic control of the clinical conditions that predispose to ECR.
\end{abstract}

Keywords: Root resorption; Orthodontic extrusion; Endodontics.

\section{Resumo}

A reabsorção cervical externa (RCE) possui natureza inflamatória e a proximidade com o sulco gengival favorece a contaminação e progressão da lesão. Alteração de cor da coroa, inflamação da gengiva marginal ou mesmo a presença de secreção no sulco gengival constituem os principais sinais clínicos. Por se tratar de lesão assintomática pode ser negligenciada e sua progressão pode condenar o dente envolvido. Este relato descreve o tratamento do caso de um paciente que apresentou dois dentes com RCE. No exame clínico a coroa do 17 apresentava por transparência coloração rósea na face oclusal. No 12 essa mancha era escura e se localizava no terço cervical da face vestibular da coroa. Ambos os dentes estavam assintomáticos e ao exame radiográfico apresentavam imagem compatível com 
reabsorção radicular no terço cervical da coroa. No 17, o terço médio e cervical da coroa estava comprometida e o teste de vitalidade pulpar foi negativo. O tratamento para o caso foi a exodontia. No 12 foi feito exame tomográfico que demonstrou o envolvimento da polpa e comprometimento da distância biológica. $\mathrm{O}$ teste de vitalidade foi positivo. Após o tratamento endodôntico, o dente foi extruído em $4 \mathrm{~mm}$, a área reabsorvida foi exposta e restaurada com resina composta. O controle clínico e radiográfico de 39 meses demonstrou integridade da superfície radicular e do periodonto. Constatou-se que o diagnóstico precoce influi no prognóstico do tratamento considerando a velocidade de progressão da reabsorção. Torna importante o controle clinico e radiográfico das condições clínicas que predispõe a RCE.

Palavras-chave: Reabsorção da raiz; Extrusão ortodôntica; Endodontia.

\section{Resumen}

La reabsorción cervical externa (CER) tiene un carácter inflamatorio y la proximidad al surco gingival favorece la contaminación y progresión de la lesión. El cambio de color de la corona, la inflamación de la encía marginal o incluso la presencia de secreción en el surco gingival son los principales signos clínicos. Al tratarse de una lesión asintomática, puede descuidarse y su progresión puede condenar el diente afectado. Este informe describe el tratamiento del caso de dos dientes con CER. En el examen clínico, la corona de 17 mostró una transparencia rosada en la superficie oclusal. Em el 12, esta mancha era oscura y estaba ubicada en el tercio cervical de la superficie vestibular. Ambos dientes estaban asintomáticos y el examen radiográfico mostró una imagen compatible con reabsorción radicular en el tercio cervical de la corona. El tercio medio y cervical de la corona del 17, estaba comprometido y la vitalidad pulpar fue negativa. El tratamiento fue la extracción. Examen tomográfico del diente 12 demostró afectación pulpar y compromiso de la distancia biológica. La vitalidad pulpar fue positiva. Después del tratamiento de endodoncia, se extruyó el diente en $4 \mathrm{~mm}$, y la área reabsorbida ha sido restaurada. El control clínico y radiográfico de 39 meses demostró integridad de la superficie radicular y del periodonto. Se encontró que el diagnóstico precoz influye en el pronóstico del tratamiento considerando la tasa de progresión de la reabsorción. Hace que sea importante el control clínico y radiográfico de las condiciones clínicas que predisponen al CER.

Palabras clave: Resorción radicular; Extrusión ortodóncica; Endodoncia.

\section{Introduction}

Root resorption corresponds to the loss of dental tissue due to the action of clastic cells on cementum and dentin (Patel, et al., 2009). In permanent teeth, it is considered a pathological process and can be classified as internal or external according to its location. A specific type of external root resorption located in the cervical region is termed by some authors as External Cervical Resorption. Other authors prefer the term "Invasive Cervical Resorption", due to its aggressive and irreversible character (Heithersay, 1999). It affects mostly the teeth present in the upper arch, especially the central incisors, irrespective of the gender (Mavridou, et al., 2017).

Its etiology can be related to previous orthodontic treatment, dental trauma, tooth whitening procedures, parafunctional habits, poor hygiene, and malocclusion (Heithersay, 1999; Mavridou, et al., 2017; Perlea, et al., 2017). These causes could act individually or in combination (Mavridou, et al., 2017). It is usually diagnosed on radiographic examinations performed for other reasons. Clinically, it can be characterized as a small defect in the gingival margin of the crown or even by the pinkish color of the tooth enamel, resulting from tissue loss beneath it (Heithersay, 1999). In the absence of these signs and being asymptomatic, the case may be neglected leading to premature loss of the dental elements involved (Patel, et al., 2018). Diagnostic methods based on radiography (Heithersay, 1999) and tomography (Patel, et al., 2018) have been proposed to favor the treatment of lesions. Currently, cone beam computed tomography (CBCT) is the best diagnostic technique due to its threedimensional properties (Patel, et al., 2018). In this case aspects such as height, circumference, and extent of its spread at the root could be assessed. The proximity of resorption to the root canal would also be better measured.

Such a resource would significantly favor the correct diagnosis of the injury, avoiding its confusion with other pathologies common to this location, such as cervical caries, abrasion, abfraction, and erosion, which despite presenting with different clinical signs, could confuse the professional (Consolaro, et al., 2014; Trope, 1998; Patel, et al., 2018). A correct diagnosis of ECR is important to define the treatment strategy since inadequate treatments could be ineffective. When properly 
conducted, treatment has proven effective for these cases, with good prognosis (Lo Giudice, et al., 2016). The present case report demonstrates the treatment of two teeth compromised by ECR, in the same patient, which presented different outcomes.

\section{Methodology}

The purpose of this paper was to report, in a descriptive way, a case study (Pereira, et al., 2018) involving ECR. The importance of this dental condition in oral health, as well as the techniques available for its treatment, its advantages and disadvantages were based on scientific articles obtained in the Pubmed database. Likewise, the results obtained were discussed, observing the advantages and disadvantages in their indication. For its realization, the diagnosis, the treatment plan, the expected results as well as the risks and benefits were informed to the patient. In the same way, the destination of the personal information collected was exposed to the patient with easy-to-understand language that he consented to through the Informed Consent Form.

\section{Case Report}

A 27-year-old male patient, sought the Dental Trauma Clinic for treatment of tooth 12 that had a darkened area on the crown and secretions in the gingival sulcus. The patient had completed orthodontic treatment, started two years back, and had no history of trauma or significant medical history. In the panoramic radiography, a radiolucent image could be seen in the cervical region of teeth 12 and 17. Clinically, tooth 17 was asymptomatic and the crown had an area of pinkish color that showed under the enamel of the occlusal surface (Figure 1A). Agenesis of tooth 18 was reported. The pulp vitality test was negative and the periapical radiography showed a radiolucent area that started on the distal surface and involved the middle and cervical third of the crown (Figure 1B). On probing, there was profuse bleeding of the periodontium, furcation involvement and rigidity of the cavity walls. After clarification and consent by the patient, the treatment plan was extraction (Figure 1C). Clinically, tooth 12 had secretion in the gingival sulcus, was asymptomatic and the vitality test was positive. The labial and lingual surfaces of the crown were healthy (Figure 1D, E). There was a small layer of composite resin on the cervical third of the labial surface of the crown. The underlying dentin was darkened (Figure 1D).

Figure 1. A- Pinkish aspect of the occlusal surface of tooth 17. B- Radiographic image of the resorbed area in the cervical and middle third of the crown of tooth 17. C- Aspect of the molar after extraction showing short roots and extent of resorption. DClinical condition of tooth 12 with darkened area of the cervical region of the crown. E- Integrity of the lingual surface of the crown of tooth 12. F: Coronary access for canal biomechanics. 

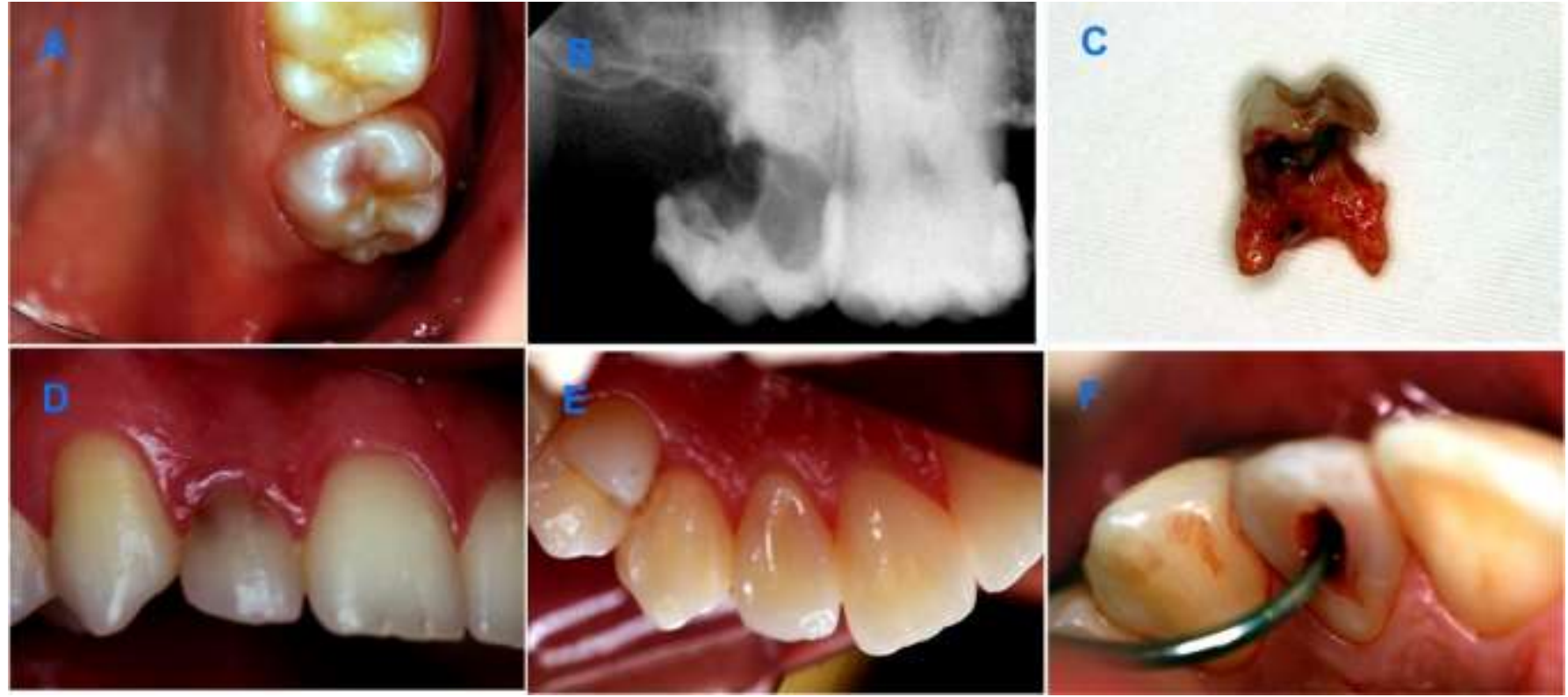

Source: Authors.

On probing the labial surface, there was profuse bleeding and a $5 \mathrm{~mm}$ gingival sulcus depth (Figure 1F). Periapical radiography showed integrity of the periodontal ligament and a radiolucent area that involved the cervical and middle third of the crown (Figure 2A). It was also possible to notice an image suggestive of the outline of the root canal in the center of the lesion (Figure 2B).

Figure 2. A- Radiographic aspect of tooth 12 with radiolucent area in the cervical region of the crown. B-: Details of the periapical radiography with an image suggestive of the root canal in the center of the crown (arrow). C-39-month radiographic control showing the integrity of the periodontal ligament.
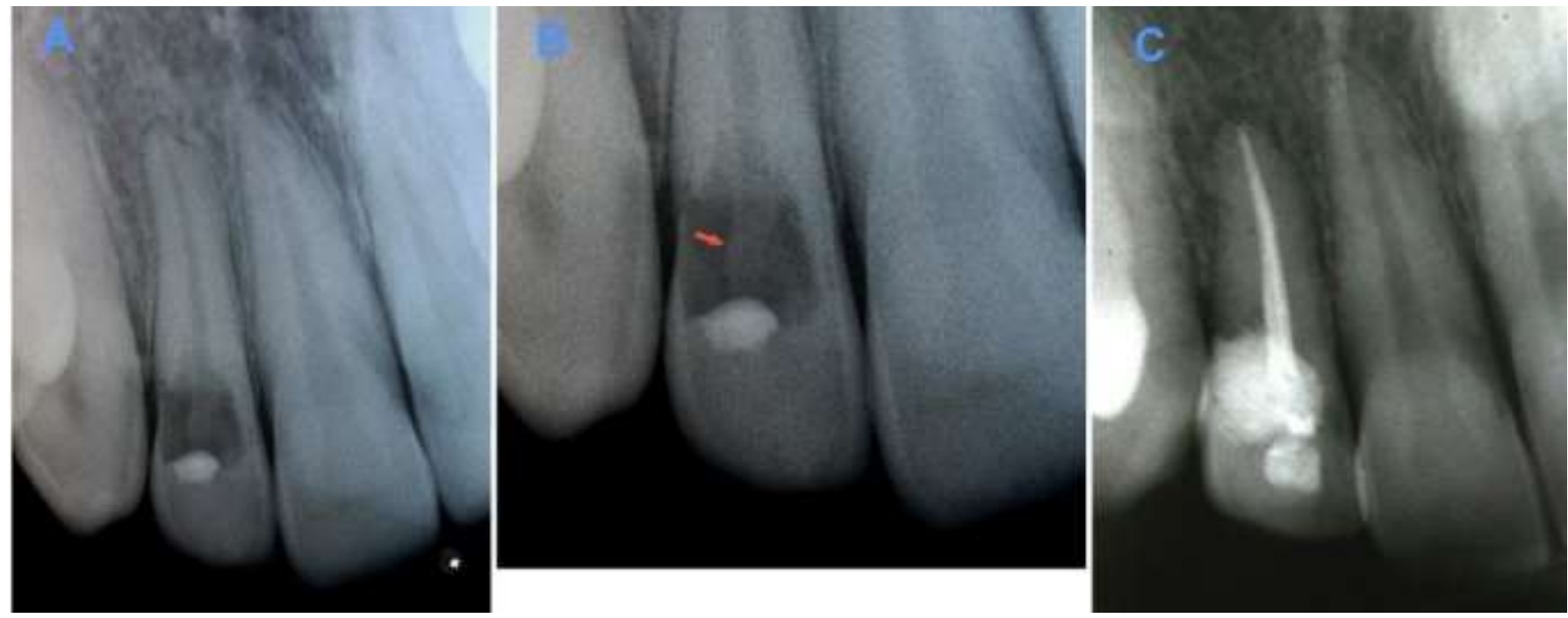

Source: Authors.

In the CT scan (Scanora 3D CBCT - Soredex Palodex Group Oy. - Finland), the coronal section revealed that the cervical limit of the lesion in the distal surface of the crown was approximately $1 \mathrm{~mm}$ from the alveolar bone crest (Figure $3 \mathrm{~A}$ ) with involvement of the pulp cavity. In the sagittal section, it was observed that the cervical limit of resorption was located approximately $3 \mathrm{~mm}$ from the alveolar bone crest. In this image (Figure 3B), it was possible to notice the presence of remains of the dentinal wall of the root canal. In the axial section, the lesion involved the entire labial surface of the crown (Figure 3C). 
Figure 3. Cone beam computed tomography images. A- Coronal section showing impairment of periodontal biological width on the distal surface of the crown and pulp involvement by resorption. B-: Sagittal section showing the location and extent of resorption on the labial surface of the crown. The remaining dentinal wall of the root canal is also noted. C-: Axial section showing extent of the lesion involving the labial surface of the crown.

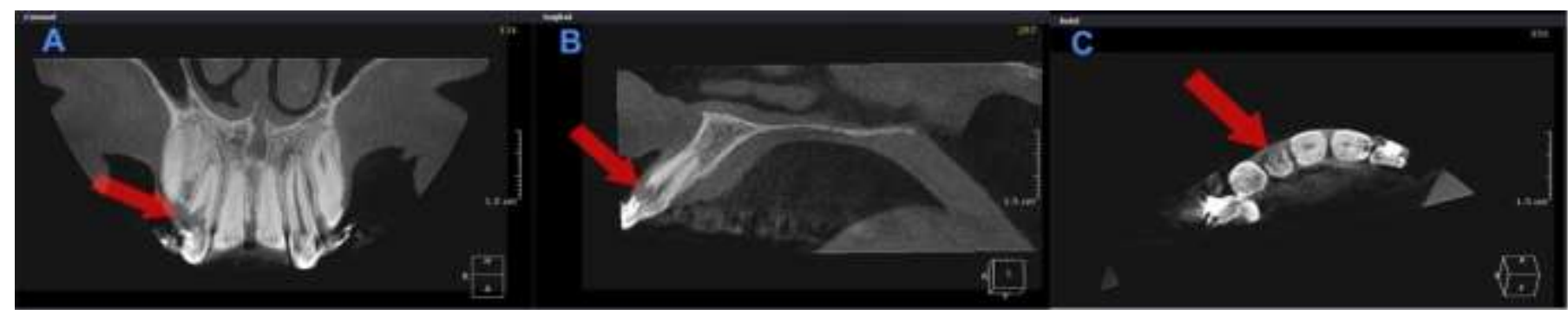

Source: Authors.

The treatment plan was explained to the patient and it consisted of endodontic treatment followed by orthodontic extrusion, and restoration of the resorbed area with composite resin. During the coronary opening for endodontic treatment (Figure 1F), it was found on probing that the communication of the resorbed area with the external environment was located 2 $\mathrm{mm}$ below the marginal gingiva (Figure 4A) and that the dentinal walls were rigid. The root canal length was $24 \mathrm{~mm}$. Calcium hydroxide dressing was used in the canal for 14 days and the final obturation was performed with gutta-percha cones and calcium hydroxide cement (Sealapex - Sybron Kerr). For orthodontic extrusion, a 0.7-inch orthodontic wire was bonded with an acid etching system and composite resin on the labial surfaces of teeth 11 and 13 to obtain anchorage. A bracket (Figure 4B) was bonded to the labial surface of tooth 12 and a 0.25 -inch orthodontic wire loop (Figure 4C) was bonded to the lingual surface, using an acid etching system and composite resin. Device activation was achieved by using 1/8-inch orthodontic elastic (Morelli Ortodontia) (Figure 4D).

After thirty days $4 \mathrm{~mm}$ of extrusion were obtained and the excess of the incisal edge was removed with a diamond bur. Apically positioned flap expose the cavity (Figure 4E). After two weeks, the area was restored with an acid etching system and composite resin. A 39-month clinical control demonstrated absence of mobility and a gingival sulcus depth of $2 \mathrm{~mm}$ (Figure 4F). On radiographic examination, the integrity of the root surface and the periodontium was observed (Figure 2C).

Figure 4. A- Probing demonstrating the location of resorption and communication with the pulp chamber. B and C- Device installed for orthodontic extrusion. D- Activation of the appliance with orthodontic elastics. E- Flap surgery to expose the resorbed area. F- Clinical control after 39 months. 

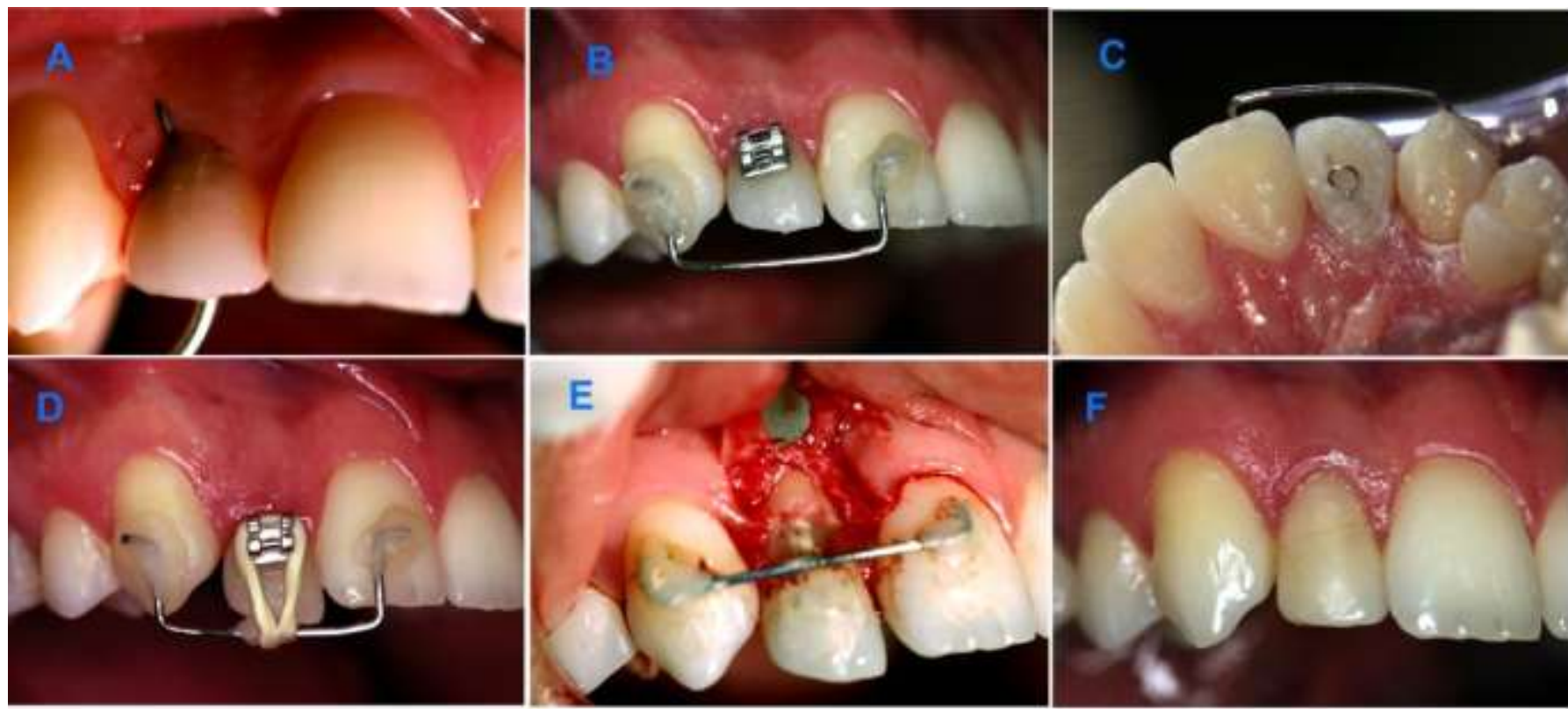

Source: Authors.

\section{Discussion}

Histologically, ECR occurs due to the loss of protection that cementoblasts and the cemental layer exert on the root surface (Patel, et al., 2009; Patel, et al., 2018). The resorbed dentin and cementum are replaced by fibrovascular tissue originating from the periodontal ligament (Gartner, et al., 1976). The progression of the lesion is a consequence of its contamination by bacteria from the gingival sulcus, which penetrate the dentinal tubules directing resorption to the center of the root. Upon reaching the supragingival region, the well-vascularized granulation tissue can be seen through the enamel as a pink stain. The resorptive process presents difficulties in affecting tooth enamel as it is more mineralized and devoid of pathways that promote communication between pulpal and periodontal tissues (Makkes, et al., 1975).

According to estudies (Patel, et al., 2018) the lesions in this case can be classified as $2 \mathrm{Bp}$, that is, it involves the coronary third of the root, extending apically to the alveolar bone crest, with a $90^{\circ}$ to $180^{\circ}$ contour of the root and with pulp involvement. These lesions could be mistaken for dental caries because they have similar radiographic characteristics. In this case, clinical aspects such as hard remaining dentin and profuse bleeding after periodontal probing contributed to the diagnosis of ECR (Trope, 1998; Patel, et al., 2018). Due to furcation involvement through resorption and the short length of the roots, the treatment plan for tooth 17 was extraction. In the case of tooth 12, a healthy remaining root favored an alternate treatment option.

The difference between diagnosis of external and internal resorption can interfere with the treatment plan. Unlike internal resorption, the pulp tissue may not be involved in the etiology of the ECR. If the lesion does not reach the pulp and it presents with vitality, there is no need for endodontic treatment (Frank, et al., 1987; Bergmans, et al., 2002; Gonzales, et al., 2007). Radiographically, internal resorption can be described as a symmetrical, eccentric lesion, with clear, defined, soft, and smooth margins. The density of the radiolucency is uniform and the contour of the pulp chamber and the root canal cannot be followed through the lesion (Cvek, 1973). In contrast, the external root resorption can be asymmetrical, with undefined edges and variations in the density of the radiolucency in the lesion body (Gulabivala, et al., 1995). The canal wall can be traced in the middle of the lesion, since it can be overlapping the root canal (Cvek, 1973). One of the resources for the diagnosis of internal and external resorption is the use of the parallax principle (Clark's technique) in radiographic imaging (Gulabivala, et al., 1995). However, radiographs are deficient in providing details of the remaining structures because they are based on a two- 
dimensional image. Thus, CBCT was used because it offers a three-dimensional image with greater precision in the location and dimension of the lesion (Patel, et al., 2018). Sagittal section demonstrated enhanced details of the existence of remains of the vestibular wall of the root canal, a characteristic of external resorption. This could be due to the presence of the pre-dentin layer that forms the root canal wall, which being a less mineralized structure, is less prone to resorption (Patel, et al., 2018; Bergmans, et al., 2002). With the coronal and axial sections, it was possible to detect the biologic width violation and the involvement of the pulp tissue.

The strategy to stop the resorptive process in cases of ECR, is to remove the connective tissue and blood supply that provide favorable conditions for maintaining the clasts next to the dentin. The resorbed area must be debrided and restored to avoid revascularization and subsequent action of the clasts (Heithersay, 1999). Among the techniques described for the treatment of ECR, the use of materials such as mineral trioxide aggregate (MTA), intentional replantation, surgery to increase the clinical crown and orthodontic extrusion are mentioned Krug, et al., 2019). In this case, the use of MTA would result in compromising aesthetics due to its dark color.16 Intentional replantation could lead to trauma to the root surface with a risk of resorption. Clinical crown augmentation surgery would result in elongation of the crown and involve the periodontium of adjacent teeth with exposure of the cementum (Batenhorst, et al. 1974; Krug, et al. 2019). Thus, orthodontic extrusion was used to expose the resorbed area and recover the biological width in a less traumatic way, allowing restoration with an aesthetic material (Heithersay, 1973; Batenhorst, et al., 1974).

In endodontic treatment, calcium hydroxide was used as a temporary dressing because of its bactericidal capacity. The release of hydroxyl ions by this material would provide action against bacteria and their toxins, which could eventually be present in the root canal and dentinal tubules (Safavi, et al., 1993). This property is also very important to prevent root resorption, especially when associated with contamination (Trope, et al., 1995). According to the literature, a sudden traumatic injury would be the most likely cause for ECR (Patel, et al., 2018). In the case of tooth 17, it could occur due to the traumatic action of the impacted third molar (Schriber, et al., 2020). However, given the history of agenesis of the third molar and the absence of some other type of trauma, reinforced orthodontic treatment seems a potential cause. Several predisposing factors, isolated or combined, could contribute to its onset and progress (Mavridou, et al., 2017). Thus, the type of orthodontic appliance used, the type of tooth movement, the force applied and the duration of treatment could be considered (Krishnan, 2005; Dudic, et al., 2017). In molars, the use of bands could expose dentin in the cervical region (Krishnan, 2005). The 39month clinical control showed normal mobility. Radiographically integrity of the root surface and the periodontium were observed indicating the effectiveness of the treatment plan.

\section{Conclusion}

It can be seen from the case that early diagnosis is important for the prognosis, considering the speed of progression of resorption. It emphasizes the importance of clinical and radiographic control of clinical conditions that could predispose to ECR. Considering orthodontic treatment as a potential etiological factor, it would be interesting to develop a study to assess the relationship between different types of tooth movement, the intensity and frequency of the force used and the occurrence of ECR.

\section{References}

Bergmans, L., Van Cleynenbreugel, J., Verbeken, E., Wevers, M., Van Meerbeek, B., \& Lambrechts, P. (2002). Cervical external root resorption in vital teeth. Journal of clinical periodontology, 29(6), 580-585. https://doi.org/10.1034/j.1600-051x.2002.290615.x

Batenhorst, K. F., Bowers, G. M., \& Williams Jr, J. E. (1974). Tissues changes resulting from facial tipping and extrusion of incisors in monkeys. Journal of periodontology, 45(9), 660-668. https://doi.org/10.1902/jop.1974.45.9.660 
Consolaro, A., Cardoso, M. A., Almeida, C. D. C. M., Souza, I. A. O., \& Capelloza Filho, L. (2014). The clinical meaning of external cervical resorption in maxillary canine: transoperative dental trauma. Dental Press Journal of Orthodontics, 19(6), 19-25. https://doi.org/10.1590/2176-9451.19.6.019-025.oin

Cvek, M. (1973). Treatment of non-vital permanent incisors with calcium hydroxide. II. Effect on external root resorption in luxated teeth compared with effect of root filling with guttapucha. A follow-up. Odontologisk revy, 24(4), 343-354.

Dudic, A., Giannopoulou, C., Meda, P., Montet, X., \& Kiliaridis, S. (2017). Orthodontically induced cervical root resorption in humans is associated with the amount of tooth movement. European Journal of Orthodontics, Volume 39, Issue 5, Pages 534-540, https://doi.org/10.1093/ejo/cjw087.

Frank, A. L., \& Bakland, L. K. (1987). Nonendodontic therapy for supraosseous extracanal invasive resorption. Journal of endodontics, 13(7), 348-355. https://doi.org/10.1016/S0099-2399(87)80117-6

Gartner, A. H., Mack, T., Somerlott, R. G., \& Walsh, L. C. (1976). Differential diagnosis of internal and external root resorption. Journal of endodontics, 2(11), 329-334. https://doi.org/10.1016/S0099-2399(76)80071-4

Gonzales, J. R., \& Rodekirchen, H. (2007). Endodontic and periodontal treatment of an external cervical resorption. Oral surgery, oral medicine, oral pathology, oral radiology, and endodontics, 104(1), e70-e77. https://doi.org/10.1016/j.tripleo.2007.01.023

Gulabivala, K., \& Searson, L.J. (1995). Clinical diagnosis of internal resorption: an exception to the rule. International endodontic journal, 28(5), 255-260. https://doi.org/10.1111/j.1365-2591.1995.tb00310.x

Heithersay, G. S. (1999). Clinical, radiologic, and histopathologic features of invasive cervical resorption. Quintessence international (Berlin, Germany: 1985), 30(1), 27-37.

Heithersay, G. S. (1973). Combined endodontic-orthdontic treatment of transverse root fractures in the region of the alveolar crest. Oral surgery, oral medicine, and oral pathology, 36(3), 404-415. https://doi.org/10.1016/0030-4220(73)90220-x

Heithersay, G. S. (1999). Invasive cervical resorption following trauma. Australian endodontic journal: the journal of the Australian Society of Endodontology Inc, 25(2), 79-85. https://doi.org/10.1111/j.1747-4477.1999.tb00094.x

Krishnan, V. (2005). Critical issues concerning root resorption: a contemporary review. World journal of orthodontics, 6(1), 30-40.

Krug, R., Soliman, S., \& Krastl, G. (2019). Intentional replantation with an atraumatic extraction system in teeth with extensive cervical resorption. Journal of endodontics, 45(11), 1390-1396. https://doi.org/10.1016/j.joen.2019.07.012

Lo Giudice, G., Matarese, G., Lizio, A., Giudice, R. L., Tumedei, M., Zizzari, V. L., \& Tetè, S. (2016). Invasive cervical resorption: a case series with 3-year follow-up. The International journal of periodontics \& restorative dentistry, 36(1), 103-109. https://doi.org/10.11607/prd.2066

Makkes, P. C., \& Thoden van Velzen, S. K. (1975). Cervical external root resorption. Journal of dentistry, 3(5), 217-222. https://doi.org/10.1016/0300$5712(75) 90126-8$

Mavridou, A. M., Bergmans, L., Barendregt, D., \& Lambrechts, P. (2017). Descriptive analysis of factors associated with external cervical resorption. Journal of endodontics, 43(10), 1602-1610. https://doi.org/10.1016/j.joen.2017.05.026

Patel, S., Dawood, A., Wilson, R., Horner, K., \& Mannocci, F. (2009). The detection and management of root resorption lesions using intraoral radiography and cone beam computed tomography - an in vivo investigation. International endodontic journal, 42(9), 831-838. https://doi.org/10.1111/j.13652591.2009.01592.x

Patel, S., Foschi, F., Condon, R., Pimentel, T., \& Bhuva, B. (2018). External cervical resorption: part 2 - management. International Endodontic Journal Nov;51(11):1224-38

Patel, S., Foschi, F., Mannocci, F., \& Patel, K. (2018). External cervical resorption: a three-dimensional classification. International endodontic journal, 51(11), 1224-1238. https://doi.org/10.1111/iej.12946

Patel, S., Kanagasingam, S., \& Pitt Ford, T. (2009). External cervical resorption: a review. Journal of endodontics, 35(5), 616-625. https://doi.org/10.1016/j.joen.2009.01.015

Patel, S., Mavridou, A. M., Lambrechts, P., \& Saberi, N. (2018). External cervical resorption-part 1: histopathology, distribution and presentation. International endodontic journal, 51(11), 1205-1223. https://doi.org/10.1111/iej.12942

Pereira, A. S., Shitsuka, D. M., Parreira, F. J., \& Shitsuka, R. (2018). Metodologia da pesquisa científica [recurso eletrônico] 1. ed. - Santa Maria, RS: UFSM, NTE. 1 e-book.

Perlea, P., Imre, M., Nistor, C. C., Iliescu, M. G., Gheorghiu, I. M., Abramovitz, I., \& Iliescu, A. A. (2017). Occurrence of invasive cervical resorption after the completion of orthodontic treatment. Romanian journal of morphology and embryology $=$ Revue roumaine de morphologie et embryologie, 58(4), 15611567.

Safavi, K. E., \& Nichols, F. C. (1993). Effect of calcium hydroxide on bacterial lipopolysaccharide. Journal of endodontics, 19(2), 76-78. https://doi.org/10.1016/S0099-2399(06)81199-4

Schriber, M., Rivola, M., Leung, Y. Y., Bornstein, M. M., \& Suter, V. (2020). Risk factors for external root resorption of maxillary second molars due to impacted third molars as evaluated using cone beam computed tomography. International journal of oral and maxillofacial surgery, 49(5), 666-672. https://doi.org/10.1016/j.ijom.2019.09.016

Trope, M. (1998). Root resorption of dental and traumatic origin: classification based on etiology. Practical periodontics and aesthetic dentistry : PPAD, $10(4), 515-522$. 
Research, Society and Development, v. 10, n. 5, e54410515340, 2021

(CC BY 4.0) | ISSN 2525-3409 | DOI: http://dx.doi.org/10.33448/rsd-v10i5.15340

Trope, M., Moshonov, J., Nissan, R., Buxt, P., \& Yesilsoy, C. (1995). Short vs. long-term calcium hydroxide treatment of estabilished inflammatory root resorption in replanted dog teeth. Endodontics \& dental traumatology, 11(3), 124-128. https://doi.org/10.1111/j.1600-9657.1995.tb00473.x 